FACTA UNIVERSITATIS

Series: Teaching, Learning and Teacher Education Vol. 4, $\mathrm{N}^{\mathrm{o}} 1,2020$, pp. 35 - 45

https://doi.org/10.22190/FUTLTE2001035M

Original research paper

\title{
THE INFLUENCE OF INTEGRATION OF PHYSICAL AND MUSIC EDUCATION ON CLASS TEACHING STUDENTS MOTOR SKILLS DEVELOPMENT
}

\author{
UDC 37.026::796::784; 371.311.4::78; 371.311.4::796.015
}

\section{Vladimir Momčilović, Vesna Zdravković}

Pedagogical Faculty in Vranje, University of Niš, Serbia

\begin{abstract}
The aim of this research was the integration of Physical and Musical activities to the development of motor skills of class teaching students. The sample of 64 survey participants consisted of primary school students, aged 9 and 10 ( \pm 6 months) from Niš and divided into two groups - experimental and control group, 32 participants in each group. The participants from the experimental group participated in the additional Physical Education lessons which included coordination and speed exercises, that is, the integrated lessons, while the survey participants from the control group were included only in regular Physical Education lessons, and also in Music Education lessons. The following motor skills were examined: Speed, Agility, Flexing, Explosive strength, Repetitive strength and Segmental speed. The obtained results show that there is a statistically significant difference in 20 meter run with the elongated start (M20VS .000), 30 meter run with the elongated start (M30VS .000), figure-of-eight agility run test

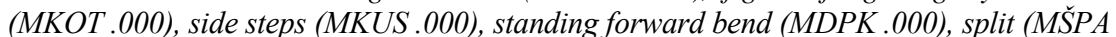
$.000)$, standing long jump (MSDM .000), standing triple jump (MTRS .000), foot tapping (MTAN .005) and hand tapping (MTAP .001). Given the results obtained, the design of a special program that would include the integration of the content of these subject areas would contribute to the development of elementary physical and musical skills.
\end{abstract}

Key words: coordination, speed, motor skills, additional integrated learning of Physical Education and Music Education

Received June 18, 2020/Accepted July 3, 2020

Corresponding author: Vladimir Momčilović

Pedagogical Faculty in Vranje, University of Niš, Partizanska 14, 17500 Vranje, Serbia

Phone: +381 17422 962•E-mail: vladmomcilovic@gmail.com

() 2020 by University of Niš, Serbia | Creative Commons License: CC BY-NC-ND 


\section{INTRODUCTION}

Based on the results of an extensive number of studies, the phenomenon of a decrease in the physical activity of primary school students is alarming. Students spend more and more leisure time in front of computers, television and other devices, which, according to numerous indicators, have multiple negative effects on their health.

According to Zdravković (2016), "as the children want to get to know the objects around them, they climb various objects, run (more like float in the air), jump, pull, lift, carry, move... throw and grab objects. By the age of three, they have perfected almost all the movements they would need in everyday life...Relative physical maturity allows children to start school around the age of seven. Most first graders have mechanisms in place that enable the regulation of the attention and observation systems, with the possibility of their voluntary control depending on the understanding of the importance of the task being performed. Given that all children experience uneven dynamics of changes in their biological growth and development, the class teaching period is characterized by a sudden increase in the overall development because the child is involved in additional physical activities...Between the age of five and nine, the development of speech organs occurs, which is followed by the expansion of the children's speech sounds. Music-related activities become conscious, controlled, one feels secure and comfortable when singing, and there is particular expressiveness in interpretation. Hearing becomes sharper thanks to the formation of the sense of tonality. There is extensive progress in the ability to keep the rhythm, whether in walking or clapping." (pp. 15-22)

With its main role, physical education aims to meet both the biological and psychological needs of children, not only for movement but also for play and creative expression. At a younger school age, the development of children's motor skills can be significantly influenced, so regular physical education classes are of special importance.

Regular Physical Education lessons, as a complex and delicate social activity aim to use physical exercises and specific forms of lesson organization and methods to trigger positive transformation of anthropological characteristics and increase the level of motor knowledge (skills) of students. Therefore, the main goal of Physical Education in the broadest sense can be defined as building and improving a complex personality with specific learning methods (Zdanski and Galić, 2002; Višnjić, 2006).

Between the age of 4 and 11, most motor skills and habits are developed, which are based on genetic and external factors that affect the overall growth and development of children (Bala, Kish and Popović, 1996). Motor skills in children between the age of 7 and 11 are best developed in the so-called "sensitive phases" (Bala, 1981; Malacko, 2002; Pržulj, 2007).

Optimal organization of Physical Education classes can lead to a significant change in the morphological characteristics and motor skills of children between the age of 7 and 11 (Pejčić, Malacko, \& Muvrin, 2014), morever, according to some authors (Gajić et al. 1985; Željaskov, 2004; Pržulj, 2006; Milanović, 2007) achieving the expected results and the development of anthropological characteristics and abilities of children depends on the proper selection and application of learning topics and physical effort appropriate to the age of students. Proper dosing of physical effort enables optimal development of physical abilities and brings the expected results in children of the appropriate age (Koprivica, 2002; Pržulj, 2007). 
"Each intentional body movement is easier to control with properly selected musical content. Physical education nurtures the traditional - folklore and circle dance, but it also includes foreign elements - rhythmic games and dance forms. It is interesting that while performing, students very often feel both as subjects and objects, both as a performer and as an instrument. Unfortunately, there are very few such contents in our teaching practice, so it is no wonder that children do not know circle dance or cannot dance in pairs. Lack of integration of musical and physical activities causes difficult adoption of the threequarter beat, which is actually a foreign element, and rhythm and movement can be successfully developed through physical education. Children's folk dances develop motor - musical skills (rhythm, tempo, dynamics, memory, and performance interpretation) and physical skills (strength, speed, endurance, flexibility, agility), in addition to all the other characteristics that games influence in children's lives. Over time, music has become an integral part of sports disciplines. The direct presence of music in some sports is justified by the fact that such music used complements the motor performance and improves it" (Zdravković, 2017, 332).

Bearing in mind everything stated above, the subject of this research was to determine the impact of the integration of Physical and Musical activities to the development of motor skills of class teaching students where coordination and speed exercise programs in Physical Education was combined with rhythmic exercises, march and children's folk dance accompanied by singing in Musical Education.

\section{METHOD}

The aim of this research was to determine the impact of the integration of Physical and Musical activities to the development of motor skills of class teaching students.

The sample of 64 survey participants consisted of primary school students, aged 9 and 10 ( \pm 6 months) from Nis and divided into two groups - experimental and control group, 32 participants in each group.

Motor skills variables used in research were: Speed ( 20 meter run with the elongated start M20VS, 30 meter run with the elongated start M30VS), Agility (figure-of-eight agility run test MKOT, side steps MKUS), Flexing (standing forward bend on a bench MDPK, Split MŠPA), Explosive strength (standing long jump MSDM, standing triple jump MTRS), Repetitive strength (Crunches with a bench MDTK, Squats MČUČ), Segmental speed (Foot tapping MTAN, Hand tapping MTAP).

Survey participants from the control group were included only in regular Physical Education lessons, and also in Music Education lessons. A total of 24 lessons were organized over 8 weeks in total.

The participants from the experimental group participated in the additional Physical Education lessons which included coordination and speed exercises, as additional exercises for the purpose of developing motor skills, which lasted for 8 weeks with 24 hours of training (three lessons a week). The integrated lessons also included 8 hours of additional music lessons.

The exercise program consisted of coordination exercises and speed exercises. The coordination exercises included: limb coordination, catch a bouncing ball, jump hurdles with turn arounds, forward roll, and backwards roll, guide the ball, limb coordination. Speed exercises that were applied: upper-extremity coordination exercises, elongated start exercises, falling start, quick steps, high knee walk, jump from one foot to the other, acceleration. 
A set of motor variables used in this research was taken from the research by Kurelić et al (1975).

Music learning topics are organized in such a way that they focus on the development of motor skills and coordination of students in that particular development period, but also at the moment of acquiring certain music knowledge and skills. In accordance with the music activities provided by the Music Curriculum of Primary School (The Curriculum for Third Grade of Primary Education, 2005, 2006, 2008 and 2010; The Curriculum for Fourth Grade of Primary Education, 2006, 2008) for students of this age, and bearing in mind those that may affect the development of motor skills, we decided to use three types of opportunities to develop these physical abilities:

- Rhythmic exercises, designed by the examiner in accordance with the cognitive abilities of students at that age, using the musical text reading method, and their manual and vocal interpretation were aligned with the changes in tempo, using an electronic metronome;

- March, walking and making movements while listening to march compositions, at the same time meeting all goals and objectives while listening to a piece of music;

- Children's folk dance accompanied by singing, which is primarily learned by ear, along with the movement choreography, after which ensues the reproduction of music by the students on children's rhythmic instruments, looking at the musical text.

The used musical contents directly influence the development of students' coordination in space while performing, and are adapted to the constant and controlled change of tempo, especially when playing certain sections on rhythmic instruments. The engagement of all necessary motor skill elements of the survey participants is present.

It is important to mention that the music used to teach the experimental group was not used in regular lessons and the participants were not familiar with these pieces of music.

Descriptive statistics and inference statistics methods were used for data analysis, and the statistical analysis software called Statistica was used. The following analyses were performed: descriptive statistics, multivariate analysis of variance, univariate analysis of variance and Student's t-test.

\section{RESEARCH RESULTS}

Table 1 shows the results for the participants from the experimental group regarding their motor skills assessment, and it indicates that there is no statistically significant deviation of the results from the normal distribution.

The results of the tests that assess the participants' motor skills indicate that the distribution is positive. This is confirmed by the results of the distribution asymmetry (skewness) which does not exceed 1.00, which means that the tests are not difficult (up to +1.00 ) or easy (up to -1.00), but correspond to the surveyed participants and the value is below one. The homogeneity (kurtosis) indicates that there is a good sensitivity of the tests, because the obtained values are below 2.75. The results obtained regarding the motor skills do not deviate from the results of similar studies conducted in our country on this population of examinees, thus it is possible to apply the multivariate analysis methods in this research as well. Generalization of the results on the population from which the sample of these respondents was derived is thus possible 
Table 1 Basic statistical parameters for the assessment of motor skills of the experimental group during the initial measurement

\begin{tabular}{lrrrrrrr}
\hline Variables & $\mathrm{N}$ & \multicolumn{1}{c}{ Mean } & \multicolumn{1}{c}{ Min. } & Max. & Std.dev. & Skewn. & Kurtos. \\
\hline M20VS & 32 & 4.26 & 3.84 & 4.90 & 1.60 & 0.335 & -1.189 \\
M30VS & 32 & 5.83 & 5.42 & 6.38 & 6.29 & 0.858 & 1.118 \\
MKOT & 32 & 21.56 & 18.70 & 24.60 & 4.39 & 0.811 & 0.798 \\
MKUS & 32 & 16.28 & 14.10 & 19.26 & 10.17 & 0.861 & 1.590 \\
MDPK & 32 & 36.82 & 28.00 & 48.00 & 2.98 & 0.056 & -0.883 \\
MŠPA & 32 & 128.36 & 112.00 & 138.00 & 7.29 & 0.483 & 0.048 \\
MSDM & 32 & 136.54 & 114.00 & 186.00 & 14.39 & -0.122 & 0.308 \\
MTRS & 32 & 410.73 & 370.00 & 460.00 & 6.96 & -0.173 & 0.611 \\
MDTK & 32 & 4.67 & 2.00 & 9.00 & 5.83 & 0.249 & 1.451 \\
MČUC & 32 & 6.24 & 3.00 & 12.00 & 2.60 & 0.487 & 0.285 \\
MTAN & 32 & 22.18 & 18.00 & 27.00 & 2.76 & 0.978 & 1.728 \\
MTAP & 32 & 28.64 & 24.00 & 35.00 & 2.70 & 0.101 & 1.404 \\
\hline
\end{tabular}

Table 2 Basic statistical parameters for the assessment of motor skills of the experimental group during the final measurement

\begin{tabular}{lcrrrrrr}
\hline Variables & $\mathrm{N}$ & \multicolumn{1}{c}{ Mean } & \multicolumn{1}{c}{ Min. } & Max. & Std.dev. & Skewn. & Kurtos. \\
\hline M20VS & 32 & 3.84 & 3.62 & 4.57 & 0.71 & 0.746 & -0.253 \\
M30VS & 32 & 5.26 & 4.82 & 6.42 & 0.38 & -0.433 & -0.403 \\
MKOT & 32 & 18.85 & 17.02 & 23.76 & 0.42 & 0.977 & -0.729 \\
MKUS & 32 & 14.52 & 13.90 & 18.90 & 6.55 & 0.372 & -0.294 \\
MDPK & 32 & 47.23 & 30.00 & 50.00 & 13.26 & 0.201 & 4.286 \\
MŠPA & 32 & 141.62 & 115.00 & 141.00 & 17.96 & 0.410 & 0.392 \\
MSDM & 32 & 157.25 & 130.00 & 188.00 & 9.37 & 0.180 & 1.032 \\
MTRS & 32 & 515.38 & 385.00 & 472.00 & 53.00 & -0.039 & -0.353 \\
MDTK & 32 & 5.12 & 4.00 & 10.00 & 43.61 & 0.443 & -0.269 \\
MČUC & 32 & 7.65 & 5.00 & 12.00 & 6.30 & -0.522 & -0.552 \\
MTAN & 32 & 29.63 & 20.00 & 29.00 & 2.47 & 0.084 & 0.122 \\
MTAP & 32 & 37.28 & 26.00 & 38.00 & 2.54 & 0.405 & 1.352 \\
\hline
\end{tabular}

Table 2 shows the results for the participants from the experimental group regarding their motor skills assessment during the final measurement, and it indicates that there is no statistically significant deviation of the results from the normal distribution. The results of the tests that assess the participants' motor skills indicate that the distribution is positive. This is confirmed by the results of the distribution asymmetry (skewness) which does not exceed 1.00, which means that the tests are not difficult (up to +1.00 ) or easy (up to -1.00), but rather correspond to the surveyed participants and the value is below one. The homogeneity (kurtosis) indicates that there is a good sensitivity of the tests, because the obtained values are below 2.75. The results obtained regarding the motor skills do not deviate from the results of similar studies conducted in our country on this population of examinees, thus it is possible to apply the multivariate analysis methods in this research as well. Generalization of the results on the population from which the sample of these respondents was derived is thus possible. 
Table 3 Basic statistical parameters for the assessment of motor skills of the control group during the initial measurement

\begin{tabular}{lrrrrrrr}
\hline Variables & $\mathrm{N}$ & \multicolumn{1}{c}{ Mean } & Min. & Max. & Std.dev. & Skewn. & Kurtos. \\
\hline M20VS & 32 & 4.29 & 3.94 & 4.83 & 2.55 & 0.207 & 2.195 \\
M30VS & 32 & 6.05 & 5.38 & 6.27 & 2.21 & 0.416 & -0.136 \\
MKOT & 32 & 21.28 & 17.90 & 23.82 & 6.22 & 0.823 & 1.058 \\
MKUS & 32 & 16.63 & 14.00 & 18.76 & 4.31 & 0.029 & 0.921 \\
MDPK & 32 & 37.52 & 22.00 & 46.00 & 10.52 & 0.002 & 2.240 \\
MŠPA & 32 & 129.27 & 115.00 & 140.00 & 3.23 & 0.846 & 0.015 \\
MSDM & 32 & 130.95 & 122.00 & 182.00 & 11.73 & 0.190 & 1.516 \\
MTRS & 32 & 420.62 & 385.00 & 475.00 & 15.78 & 0.129 & -0.271 \\
MDTK & 32 & 5.10 & 3.00 & 12.00 & 4.29 & -0.023 & 1.380 \\
MČUC & 32 & 6.78 & 4.00 & 14.00 & 4.68 & 0.727 & 0.637 \\
MTAN & 32 & 23.52 & 19.00 & 26.00 & 2.60 & 0.043 & 2.449 \\
MTAP & 32 & 30.24 & 24.00 & 38.00 & 2.62 & 0.715 & 2.206 \\
\hline
\end{tabular}

Table 3 shows the results for the participants from the control group regarding their motor skills assessment during the initial measurement, and it indicates that there is no statistically significant deviation of the results from the normal distribution. The results of the tests that assess the participants' motor skills indicate that the distribution is positive. This is confirmed by the results of the distribution asymmetry (skewness) which does not exceed 1.00, which means that the tests are not difficult (up to +1.00) or easy (up to -1.00), but rather correspond to the surveyed participants and the value is below one. The homogeneity (kurtosis) indicates that there is a good sensitivity of the tests, because the obtained values are below 2.75. The results obtained regarding the motor skills do not deviate from the results of similar studies conducted in our country on this population of examinees, thus it is possible to apply the multivariate analysis methods in this research as well. Generalization of the results on the population from which the sample of these respondents was derived is thus possible.

Table 4 Basic statistical parameters for the assessment of motor skills of the control group during the final measurement

\begin{tabular}{lrrrrrrr}
\hline Variables & $\mathrm{N}$ & \multicolumn{1}{c}{ Mean } & \multicolumn{1}{c}{ Min. } & Max. & Std.dev. & Skewn. & Kurtos. \\
\hline M20VS & 32 & 4.23 & 3.89 & 4.80 & 7.11 & 0.553 & -0.233 \\
M30VS & 32 & 5.96 & 5.26 & 6.24 & 12.56 & 0.912 & 1.650 \\
MKOT & 32 & 21.75 & 17.68 & 23.47 & 17.83 & 0.282 & -0.852 \\
MKUS & 32 & 16.48 & 14.00 & 18.19 & 9.02 & -0.359 & 0.272 \\
MDPK & 32 & 38.13 & 26.00 & 50.00 & 42.60 & -0.219 & -0.941 \\
MŠPA & 32 & 131.62 & 120.00 & 145.00 & 30.18 & -0.201 & 0.739 \\
MSDM & 32 & 134.24 & 129.00 & 187.00 & 6.38 & -0.285 & 0.387 \\
MTRS & 32 & 432.79 & 390.00 & 482.00 & 4.24 & 0.247 & 0.896 \\
MDTK & 32 & 5.83 & 4.00 & 12.00 & 3.50 & -0.042 & -0.953 \\
MČUČ & 32 & 8.24 & 5.00 & 16.00 & 0.86 & -0.341 & -0.827 \\
MTAN & 32 & 24.10 & 21.00 & 29.00 & 0.61 & 0.568 & -0.580 \\
MTAP & 32 & 31.45 & 26.00 & 41.00 & 0.34 & -0.814 & -0.084 \\
\hline
\end{tabular}

Table 4 shows the results for the participants from the control group regarding their motor skills assessment during the initial measurement, and it indicates that there is no 
statistically significant deviation of the results from the normal distribution. The results of the tests that assess the participants' motor skills indicate that the distribution is positive. This is confirmed by the results of the distribution asymmetry (skewness) which does not exceed 1.00, which means that the tests are not difficult (up to +1.00 ) or easy (up to -1.00), but rather correspond to the surveyed participants and the value is below one. The homogeneity (kurtosis) indicates that there is a good sensitivity of the tests, because the obtained values are below 2.75. The results obtained regarding the motor skills do not deviate from the results of similar studies conducted in our country on this population of examinees, thus it is possible to apply the multivariate analysis methods in this research as well. Generalization of the results on the population from which the sample of these respondents was derived is thus possible.

Table 5 Multivariate analysis of variance of motor skills between the experimental and control group during the initial measurement

\begin{tabular}{ll}
\hline Wilk's Lambda Test & .532 \\
Rao's F-approximation & 1.65 \\
$\mathrm{Q}$ & .143 \\
\hline
\end{tabular}

Table 5 shows the results of the level of significance in the differences of means for all motor skills tests between the initial measurements for the experimental and for the control group, and these results indicate that there is no statistically significant difference, since WILK'S LAMBDA is .532 and Rao's F-approximation of 1.65 level result in the level of significance $Q=.143$. Therefore, no statistically significant differences were found regarding the examined motor skills of the study participants.

Table 6 Univariate analysis of variance of motor skills assessment for the experimental and control group of participants during the initial measurement

\begin{tabular}{lrrcc}
\hline Tests & Mean $(\mathrm{E})$ & Mean $(\mathrm{K})$ & F-approximation & $\mathrm{Q}$ \\
\hline M20VS & 4.26 & 4.29 & 1.26 & .251 \\
M30VS & 5.83 & 6.05 & 1.80 & .075 \\
MKOT & 21.56 & 21.28 & 1.28 & .241 \\
MKUS & 16.28 & 16.63 & 1.75 & .329 \\
MDPK & 36.82 & 37.52 & 1.88 & .068 \\
MŠPA & 128.36 & 129.27 & 1.56 & .145 \\
MSDM & 136.54 & 130.95 & 1.52 & .175 \\
MTRS & 410.73 & 420.62 & 1.35 & .122 \\
MDTK & 4.67 & 5.10 & 1.42 & .114 \\
MČUČ & 6.24 & 6.78 & 1.48 & .179 \\
MTAN & 22.18 & 23.52 & 1.87 & .088 \\
MTAP & 28.64 & 30.24 & 1.39 & .132 \\
\hline
\end{tabular}

Table 6 shows the univariate analysis of variance of motor skills assessment by comparing the result means for the experimental and control group of participants during the initial measurement. Based on the F-approximations and their significance (P-Level), it can be concluded that no statistically significant difference in the level of motor skills between the experimental and control group was found. 
Table 7 Significance of differences between the means for the experimental group

\begin{tabular}{lcccc}
\hline Tests & Mean $(\mathrm{i})$ & Mean $(\mathrm{f})$ & T-value & $\mathrm{p}$ \\
\hline M20VS & 4.26 & 3.84 & 7.58 & .000 \\
M30VS & 5.83 & 5.26 & 8.55 & .000 \\
MKOT & 21.56 & 18.85 & 5.60 & .000 \\
MKUS & 16.28 & 14.52 & 9.13 & .000 \\
MDPK & 36.82 & 47.23 & 5.94 & .000 \\
MŠPA & 128.36 & 141.62 & 4.96 & .000 \\
MSDM & 136.54 & 157.25 & 12.39 & .000 \\
MTRS & 410.73 & 515.38 & 11.29 & .000 \\
MDTK & 4.67 & 5.12 & 1.17 & .330 \\
MČUČ & 6.24 & 7.65 & 1.72 & .090 \\
MTAN & 22.18 & 29.63 & 3.29 & .005 \\
MTAP & 28.64 & 37.28 & 3.96 & .001 \\
\hline
\end{tabular}

Table 7 shows the results of the T-test of motor skills between the initial and final measurements for the experimental group. After analyzing the results, it was concluded that there is a statistically significant difference in the 20 meter run with the elongated start (M20VS .000), 30 meter run with the elongated start (M30VS .000), figure-of-eight agility run test (MKOT .000), side steps (MKUS .000), standing forward bend (MDPK .000 ), split (MŠPA .000), standing long jump (MSDM .000), standing triple jump (MTRS .000), foot tapping (MTAN .005) and hand tapping (MTAP .001).

Table 8 Significance of differences between the means for the control group

\begin{tabular}{lrrrc}
\hline Tests & Mean(i) & Mean(f) & T-value & $\mathrm{p}$ \\
\hline M20VS & 4.29 & 4.23 & 0.42 & .569 \\
M30VS & 6.05 & 5.96 & 1.51 & .194 \\
MKOT & 21.28 & 21.75 & -1.20 & .299 \\
MKUS & 16.63 & 16.48 & -1.54 & .197 \\
MDPK & 37.52 & 38.13 & -1.54 & .289 \\
MŠPA & 129.27 & 131.62 & -1.22 & .277 \\
MSDM & 130.95 & 134.24 & 1.26 & .349 \\
MTRS & 420.62 & 432.79 & 1.83 & .099 \\
MDTK & 5.10 & 5.83 & -1.59 & .183 \\
MČUČ & 6.78 & 8.24 & -1.74 & .103 \\
MTAN & 23.52 & 24.10 & 1.17 & .425 \\
MTAP & 30.24 & 31.45 & -1.47 & .122 \\
\hline
\end{tabular}

Table 8 shows the results of the T-test of motor skills between the initial and final measurements for the control group. After analyzing the results, it was concluded that there were no statistically significant difference in the motor skills tests.

Table 9 Multivariate analysis of variance of motor skills between the experimental and control group during the final measurement

\begin{tabular}{ccc}
\hline Wilks' Lambda & Rao's R & Q \\
\hline .101 & 24.74 & .000 \\
\hline
\end{tabular}


Table 9 shows the results of the multivariate analysis of variance between the experimental and control group during the final measurement, and they indicate that there is a statistically significant intergroup difference in motor skills since WILK'S LAMBDA is .101, while the Rao's F-approximation of 24.74 results in the significance of differences of $\mathrm{Q}=.000$. Therefore, statistically significant differences were found regarding the examined motor skills of the study participants.

Table 10 Univariate analysis of variance of motor skills assessment for the experimental and control group of participants during the final measurement

\begin{tabular}{lcccc}
\hline Tests & Mean $(\mathrm{E})$ & Mean $(\mathrm{K})$ & F-approximation & $\mathrm{Q}$ \\
\hline M20VS & 3.84 & 4.23 & 4.58 & .000 \\
M30VS & 5.26 & 5.96 & 7.59 & .000 \\
MKOT & 18.85 & 21.75 & 8.89 & .000 \\
MKUS & 14.52 & 16.48 & 9.45 & .000 \\
MDPK & 47.23 & 38.13 & 6.88 & .000 \\
MŠPA & 141.62 & 131.62 & 6.45 & .000 \\
MSDM & 157.25 & 134.24 & 6.31 & .000 \\
MTRS & 515.38 & 432.79 & 4.34 & .000 \\
MDTK & 5.12 & 5.83 & 1.46 & .135 \\
MČUČ & 7.65 & 8.24 & 1.16 & .419 \\
MTAN & 29.63 & 24.10 & 3.59 & .004 \\
MTAP & 37.28 & 31.45 & 3.82 & .002 \\
\hline
\end{tabular}

Table 10 shows the univariate analysis of variance of motor skills test by comparing the result means for the experimental and control group of participants during the final measurement. Based on the F-approximations and their significance (P-Level), it can be concluded that there is a statistically significant difference in the level of motor skills between the experimental and control group for the following: the 20 meter run with the elongated start (M20VS .000), 30 meter run with the elongated start (M30VS .000), figure-of-eight agility run test (MKOT .000), side steps (MKUS .000), standing forward bend (MDPK .000), split (MŠPA .000), standing long jump (MSDM .000), standing triple jump (MTRS .000), foot tapping (MTAN .005) and hand tapping (MTAP .001).

\section{DISCUSSION AND CONCLUSION}

A large number of studies on this and similar topics indicate that the programmed exercises in the additional classes of Physical Education as well as the optimal programming of physical education classes significantly affect the transformation of anthropological characteristics of children (Malacko, 2002; Višnjić, 2006; Gajić et al, 1985; Željaskov, 2004; Pržulj, 2006; Milanović, 2007; Bala, 1981; Pržulj, 2007; Pejčić, Malacko \& Muvrin, 2014).

The studies conducted so far and the results of this research lead us to the following conclusions:

Based on the results of multivariate and univariate analysis of the variance of motor skills between the experimental and control group of examinees at the initial measurement (Table 5 and Table 6), it can be concluded that there is no statistically significant difference in motor skills between experimental and control groups. 
The analysis of the results of the T-test of motor skills between the initial and final measurements for the experimental group (Table 7) shows us that there is a statistically significant difference in the 20 meter run with the elongated start (M20VS .000), 30 meter run with the elongated start (M30VS .000), figure-of-eight agility run test (MKOT .000), side steps (MKUS .000), standing forward bend (MDPK .000), split (MŠPA .000), standing long jump (MSDM .000), standing triple jump (MTRS .000), foot tapping (MTAN .005) and hand tapping (MTAP .001); however, as for the repetitive strength variable (Crunches with a bench MDTK, Squats MČUČ), there is no statistically significant difference.

The results of the T-test of motor skills between the initial and final measurements for the control group (Table 8) and their analysis indicate that there is no statistically significant difference in the motor skills tests.

Based on the results of the multivariate analysis of variance between the experimental and control group during the final measurement (Table 9), and the univariate analysis of variance of motor skills assessment by comparing the result means for the experimental and control group of participants during the final measurement (Table 10), we can conclude that there is a statistically significant difference in the level of motor skills between the experimental and control group for the following: the 20 meter run with the elongated start (M20VS .000), 30 meter run with the elongated start (M30VS .000), figure-of-eight agility run test (MKOT .000 ), side steps (MKUS .000), standing forward bend (MDPK .000), split (MŠPA .000), standing long jump (MSDM .000), standing triple jump (MTRS .000), foot tapping (MTAN .005 ) and hand tapping (MTAP .001); however, as for the repetitive strength variable (Crunches with a bench MDTK, Squats MČUČ), there is no statistically significant difference.

The results obtained in this research and their analysis lead us to the conclusion that there is a statistically significant impact of the coordination and speed exercise program on the motor skills of class teaching (primary school) students.

The conclusion offered by the initiator of this research is directed towards the effect of the integrated learning curriculum for Physical Education and Music Education, primarily for the purposes of developing students' motor skills and their coordination! This research was not focused on specific music abilities; however, significant improvement of these skills was noticed as well. This particular issue in class teaching could be the subject of some future study from the aspect of the integrated learning approach used in teaching these particular subjects in the classroom, but also in the acquisition of these primary skills by students.

\section{REFERENCES}

Bala, G. (1981). Struktura i razvoj morfoloških i motoričkih dimenzija dece SAP Vojvodine [The structure and development of morphological and motor dimensions of children]. Novi Sad: Fakultet fizičke kulture.

Bala, G., Kiš, M., and Popovic, B. (1996). Training in the development of motor behavior of young children. The coaching in the development of motor behavior of small children. In: Yearbook 8, 83-87. Belgrade: Faculty of Physical Education.

Gajić M. et al. (1985). Osnovi motorike čovjeka [Fundamentals of human motor skills]. Novi Sad: Fakultet fizičke kulture.

Koprivica, V. (2002). Osnove sportskog treninga [Fundamentals of sports training]. Beograd: SIA.

Kurelic, N. et al. (1975). Struktura $i$ razvoj morfoloskih $i$ motorickih dimenzija omladine [Structure and development of morphological and motor dimensions in youth]. Beograd: Institut za naucna istrazivanja Fakulteta za fizicko vaspitanje Univerziteta u Beogradu.

Malacko, J. (2002). Sportski trening [Sports Training]. Novi Sad: Fakultet fizičke kulture. 
Milanović, D. (2007). Teorija treninga, Priručnik zastudente sveučilišnog studija [The Theory of Training, Handbook for University Students]. Zagreb: Kineziološki fakultet Sveučilišta u Zagrebu.

Nastavni program za treći razred osnovnog obrazovanja i vaspitanja [The Curriculum for Third Grade of Primary Education]. Službeni glasnik Republike Srbije - Prosvetni glasnik, br. 1, 2005, br. 15, 2006, br. 2, 2008, br.2, 2010

Nastavni program za četvrti razred osnovnog obrazovanja i vaspitanja [The Curriculum for Fourth Grade of Primary Education]. Službeni glasnik Republike Srbije - Prosvetni glasnik, br. 3, 2006, br. 15, 2006, br.2, 2008.

Pejĉić, A., Malacko, J., \& Muvrin, H. (2014). Gender differences in the morphological characteristics and motor skills of first-fourth grade elementary school children. In D. Milanović and G. Sporiš (Eds.), 7th International Scientific Conference on Kinesiology (pp. 286-290). Opatija, Croatia.

Pržulj, D. (2006). Osnovi antropomotorike [Fundamentals of Anthropomotorics]. Pale: Fakultet fizičke kulture.

Pržulj, D. (2007). Efekti kondicione pripreme na razvoj motoričkih sposobnosti mladih sportista u pripremnom period [Effects of Physical Conditioning Training on the Development of Motor Skills in Young Athletes during the Preparatory Period]. Sport $i$ zdravlje, 2(1), 5-8.

Višnjić, D. (2006). Nastava fizičkog vaspitanja: od V do VIII razreda osnovne škole: Priručnik za studente, nastavnike $i$ profesore [Physical Education: from $5^{\text {th }}$ to $8^{\text {th }}$ Grade of Primary School: Handbook for students, teachers and professors]. Beograd: Zavod za udžbenike i nastavna sredstva.

Zdanski, I., i Galić, M. (2002). Didaktika fizičkog vaspitanja, Organizacioni oblici nastave u fizičkom vaspitanju [Didactics of physical education, Types of Organizing Physical Education Lessons] (148-165). Banja Luka: Fakultet fizičkog vaspitanja i sporta.

Zdravković, V. (2016). Integrativni pristup početnoj muzičkoj nastavi u osnovnoj školi [Integrative Approach in Initial Music Education in Primary School] (Doktorska disertacija) [Doctoral Thesis]. Vranje: Pedagoski fakultet.

Zdravković, V. (2017). Integrativni pristup početnoj muzičkoj nastavi u osnovnoj školi [Integrative Approach in Initial Music Education in Primary School], Godisnjak Pedagoškog fakulteta u Vranju, VIII, 325-341.

Željaskov, C. (2004). Kondicioni trening vrhunskih sportista [Conditioning Training of Top Athletes]. Beograd: Sportska akademija.

\section{UTICAJ INTEGRATIVNE NASTAVE FIZIČKOG VASPITANJA I MUZIČKE KULTURE NA RAZVOJ MOTORIČKIH SPOSOBNOSTI UČENIKA RAZREDNE NASTAVE}

Ovo istraživanje imalo je za cilj utvrđivanje uticaja integracije Fizičkog vaspitanja i Muzičke kulture na motoričke sposobnosti učenika razredne nastave. Uzorak od 64 ispitanika činili su učenici osnovnih škola, uzrasta 9 i 10 godina ( 6 meseci) u Nišu koji su podeljeni u dve grupe, eksperimentalnu i kontrolnu sa po 32 ispitanika u svakoj grupi. Ispitanici eksperimentalne grupe bili su uključeni u process vežbanja koordinacije $i$ brzine u integrisanoj nastavi Fizičkog vaspitanja $i$ Muzičke kulture, dok su ispitanici kontrolne grupe bili ukljuceni samo u redovnu nastavu Fizičkog vaspitanja, ali i nastave Muzičke kulture. Na osnovu rezultata doobijenih u istraživanju zaključeno je da postoji statistički značajna razlika u trčanju na 20 metara visokim startom (M20VS .000), trčanju na 30 metara visokim startom (M30VS .000), koverti testu (MKOT .000), koracima u stranu (MKUS .000), dubokom pretklonu (MDPK .000), špagatu (MŠPA .000), skoku u dalj iz mesta (MSDM .000), troskoku iz mesta (MTRS .000), tapingu nogom (MTAN .005) i tapingu rukom (MTAP .001). $S$ obzirom na dobijene rezultate, osmišljavanje posebnog programa koji bi podrazumevao integraciju sadržaja ovih predmetnih oblasti, doprineo bi razvoju elementarnih fizičkih i muzičkih veština.

Ključne reči: koordinacija, brzina, motoričke sposobnosti, dodatna integrativna nastava predmeta Fizičko vaspitanje i Muzička kultura 